\title{
Per Thousand Cells
}

National Cancer Institute

\section{Source}

National Cancer Institute. Per Thousand Cells. NCI Thesaurus. Code C116240.

A unit of measure equal to the instances of an entity per 1000 cells. 